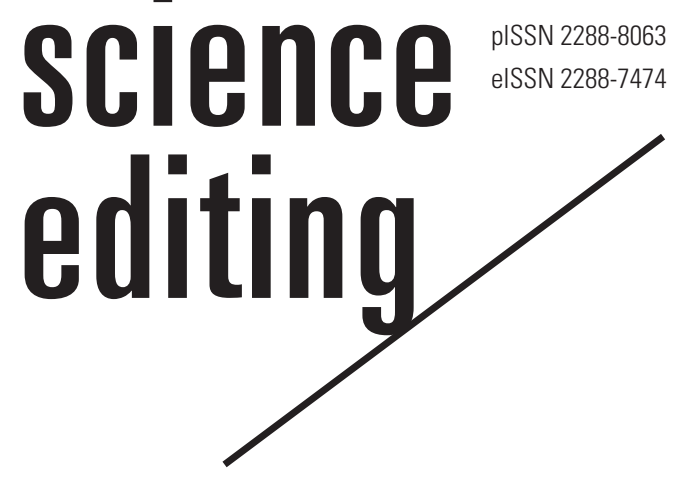

\title{
Presidential address: the Korean Council of Science Editors as a board member of Crossref from March 2021 to February 2024
}

\author{
Sun Huh \\ Department of Parasitology and Institute of Medical Education, College of Medicine, Hallym University, Chuncheon, Korea
}

I heard the news that the Korean Council of Science Editors (KCSE) was elected as a board member of Crossref at Crossref Live 2020 at 2:00 a.m. on November 11, 2020. The representative of KCSE to Crossref was chosen to be Prof. Kihong Kim, vice-president of the KCSE (2020-2023) and the next president (2023-2026). Four members of the KCSE attended Crossref Live 2020 through Zoom online. In this address, I aim to present the process of the election and the history of the introduction of digital object identifiers (DOIs) in Korea.

On June 30, 2020, I received an email from the Crossref Nominating Committee stating that if any members of Crossref would be interested in serving on the Crossref Board starting in 2021, they should submit an expression of interest. I asked Prof. Kim to send an expression of interest in serving as a delegate from the KCSE. After doing so, Prof. Kim was interviewed by two nominating committee members of Crossref. I then learned that the KCSE became one of five candidate board members for Tier 1 (small and mid-sized members) on October 1, 2020. Out of the five candidates, KCSE was the only editors' organization. On the ballot, four out of the five candidates were elected. We, as Korean and Asian science editors, should take pride in this achievement.

The suggested roles of a board member of Crossref are as follows: "To provide strategic and financial oversight of the organization, as well as guidance to the Executive Director and the staff leadership team, with the key responsibilities being: setting the strategic direction for the organization; providing financial oversight; and approving new policies and services." Each board member also serves on at least one committee.

Crossref is one of ten DOI registration agencies, which deal with scholarly publications including books and journals. The DOI is the unique identifier on a website that directs to the full-text document of each article or book even if its URL is changed. It launched in 2000. This

Received: January 25, 2021 Accepted: January 25, 2021

Correspondence to Sun Huh shuh@hallym.ac.kr

ORCID

Sun Huh

https://orcid.org/0000-0002-8559-8640 20-year-old organization has now broadened its scope to services like Event Data [1] and the funder registry. Its scope will be extended to support the Research Organization Registry, an initiative that Crossref runs as part of collaboration [2]. Crossref is now a mainstay of scholarly publishing, as many services provided by Crossref are essential for journal publishing. Although other agencies of the DOI Foundation may resolve DOIs themselves, Crossref also provides other journal publishing services to help ensure journals' scientific integrity, such as 
science editing /

Crossmark and the registration of funding metadata. Crossref conducted a survey and interviews to hear members' voices to prepare developmental strategies for 2040. I am confident that Crossref will continue to provide services for scholarly journals, especially for local journals, because of its contribution to the academic journal network [3].

In Korea, only some journals published by large commercial companies were equipped with DOIs as of the early 2000s. At that time, many society journal editors had not heard of DOIs because they did not have the opportunity to find out about such innovations by communicating with international editors or publishers. The International Federation of Library Associations and Institutions held a conference in Seoul from August 20 to 24, 2006. Prof. Ian M. Johnson from the Robert Gordon University, United Kingdom mentioned DOIs in his presentation as follows [4]: "to meet the growing demands of users for links to cited papers, CrossRef was developed to enable publishers to provide reference linking between electronic journals, using a Digital Object Identifier system to provide permanent online access to the full text of identified documents."

His presentation might have been the first introduction of DOIs in Korea. The late Prof. Seung-Yull Cho [5] attended that conference. He said to me that he heard that DOIs would be useful for journal publication at the conference. At that time, I was serving as the chair of the Information Management Committee of the Korean Association of Medical Journal Editors. It was possible to produce Crossref XML to deposit DOIs. In August 2007, the first Crossref XML file deposition was done for a society journal, the Journal of the Korean Ophthalmological Society, which has been published since 1958. Until 2011, many science journal editors in Korea were still not familiar with DOIs. A turning point was a change in the journal support policy of the Korean Federation of Science and Technology Societies, which provides funding for science society journals annually. In January 2012, the Korean Federation of Science and Technology Societies announced a new journal evaluation tool [6], in which one of the minimum conditions was the existence of a DOI for each article. Subsequently, most scientific, technological, and medical journals began to deposit Crossref XML files for DOIs. This policy change dramatically increased the number of journals with DOIs from 256 (47.1\%) in 2011 to 536 (98.5\%) in 2019, out of 544 journals [7]. The DOI has also become a prestigious component in journal publishing in the humanities and social sciences because, in 2020, the National Research Foundation of Korea started to add 1 point (out of 100) in their journal evaluation score for funding if a journal is equipped with DOIs [8]. Although it is still not mandatory, as has been the case for science journals since 2012, this DOI policy will give the editors of humanities and social science journals an incentive to add DOIs to their journals. I hope that all scholarly journals from Korea will be equipped with DOI so that they can be included in the international scholarly journal network. The adoption of DOIs will be the best chance for local journals to expand their audience to readers around the world.

Many scholarly journals from Korea have been treated as local journals for a long time, meaning that authors, readers, and editors are primarily from Korea. Journals should be included in international databases, including Scopus, Web of Science, CAS, Biosis Preview, Agricola, ERIC, and PubMed, to overcome this limitation. Another good solution is to link references through DOIs. Through the cited-by function, if a local journal cites other articles, the citing journal can be identified from the cited article. This function can facilitate an appreciation of the work done by local journals.

KCSE is the first board member of Crossref from the Asian continent since Crossref's establishment in 2000. It may reflect the rapid increase of scholarly publications from Asia. Of particular note, beyond scholarly activity in East Asia, the number of journals from Southeast Asia has exploded. In China, the number of scholarly journals in 2003 exceeded 8,000 , of which more than 4,600 could be considered scientific [9]. In Indonesia, there were 5,900 scientific journals in 2014 [10]. In Korea, there are 5,822 scholarly journals as of January 2021, according to the KCI database [11]. However, some of these journals still have not adopted the DOI system. To provide DOIs for articles, publishers in Korea should contact either Crossref, an agency for scholarly publishing, or the Korea Institute of Science and Technology Information, as the DOI agency in Korea.

As a delegate from Asia to Crossref, the KCSE will continue to pay close attention to the concerns of editors and publishers in Asia through the Council of Asian Science Editors.

\section{Conflict of Interest}

Sun Huh has been the president of the Korean Council of Science Editors since January 2020, but had no role in the decision to publish this editorial. No other potential conflict of interest relevant to this article was reported.

\section{Funding}

The author received no financial support for this editorial.

\section{References}

1. Lammey R. How publishers can work with Crossref on data 
citation. Sci Ed 2019;6:166-70. https://doi.org/10.6087/ kcse. 165

2. Lammey R. Solutions for identification problems: a look at the Research Organization Registry. Sci Ed 2020;7:65-9. https://doi.org/10.6087/kcse.192

3. Lammey R. Crossref at 20 years: what do the community need? Sci Ed 2020;7:125-9. https://doi.org/10.6087/kcse.206

4. Johnson IM. Breaking out of the linguistic ghetto? The role of new media in facilitating international research. In: World Library and Information Congress: 72nd IFLA General Conference and Council; 2006 Aug 20-24; Seoul, Korea. Available from: https://archive.ifla.org/IV/ifla72/ papers/145-Johnson-en.pdf

5. Kong Y. Professor Seung-Yull Cho (1943-2019). Korean J Parasitol 2019;57:77-8. https://doi.org/10.3347/kjp.2019.57.1.77

6. Jeong GH, Huh S. Analysis of the suitability of the Korean Federation of Science and Technology Societies journal evaluation tool. Learn Publ 2016;29:193-8. https://doi.org/10. 1002/leap.1037
7. Seo YJ, Cho HM, Huh S. Changes in bibliographic information associated with Korean scientific journals from 2011 to 2019. Sci Ed 2020;7:11-5. https://doi.org/10.6087/ kcse. 184

8. National Research Foundation of Korea. Public offering of scholarly journal support (humanities and social science fields) in 2020 [Internet]. Daejeon: National Research Foundation of Korea; 2020 [cited 2021 Jan 24]. Available from: https://www.kci.go.kr/

9. Jinxiu L. Scientific publication in China: an overview and some thoughts on improvement. Sci Ed 2004;27:120-1.

10. Wiryawan KG. The current status of science journals in Indonesia. Sci Ed 2014;1:71-5. https://doi.org/10.6087/ kcse.2014.1.71

11. National Research Foundation of Korea. Number of scholarly journals in Korea [Internet]. Daejeon: National Research Foundation of Korea; 2021 [cited 2021 Jan 24]. Available from: https://www.kci.go.kr/kciportal/po/statistics/poStatisticsMain.kci 